\title{
Ellipsis
}

Volume 45

Article 8

2018

\section{Gaspard the nightwalker}

Shaina Monet

University of New Orleans

Follow this and additional works at: https://scholarworks.uno.edu/ellipsis

\section{Recommended Citation}

Monet, Shaina (2018) "Gaspard the nightwalker," Ellipsis: Vol. 45 , Article 8.

DOI: https://doi.org/10.46428/ejail.45.08

Available at: https://scholarworks.uno.edu/ellipsis/vol45/iss1/8

This Poetry is brought to you for free and open access by the Department of English and Foreign Languages at ScholarWorks@UNO. It has been accepted for inclusion in Ellipsis by an authorized editor of ScholarWorks@UNO.

For more information, please contact scholarworks@uno.edu. 


\section{SHAINA MONET}

\section{Gaspard the nightwalker}

Honorable Mention for the Andrea Saunders Gereighty Award

you, ever-bright, like the flames of this

land, refuse to land.

like fire, these rocks glint in a surprise

of ground-fog. you can see

this, too-watching it burn. grey

parts for the air. the whoosh of sky

and the moon, more than half-closed,

gloat much-too much for comfort

for you. so what if I would rather

watch from here-see the flames

as a house does - with no idea

of sealing, but for what one has

taught and housed it with.

this is my argument. do understand.

some call me the nightwalker,

because I cannot be seen-am

essentially invisible. I can set fire

to bodies, then flirt a feather back

into tempered symmetry. darling-

when I dare you back, I feel nothing

for you. walk out onto the air. 